\title{
Soil moisture in forage cactus plantations with improvement practices for their resilience
}

\author{
Ailton A. de Carvalho' ${ }^{1}$, Thieres G. F. da Silva ${ }^{2}$, Luciana S. B. de Souza ${ }^{2}$, \\ Magna S. B. de Moura ${ }^{3}$, Gherman G. L. de Araujo ${ }^{3}$ \& Matheus P. S. Tolêdo \\ ${ }^{1}$ Universidade Federal Rural de Pernambuco/Departamento de Engenharia Agrícola. Recife, PE. E-mail: ailtonalvesst@hotmail.com (Corresponding author) \\ ${ }^{2}$ Universidade Federal Rural de Pernambuco/Unidade Acadêmica de Serra Talhada. Serra Talhada, PE. E-mail: thieres_freire@yahoo.com.br; \\ sanddrabastos@yahoo.com.br; matheustoledo@hotmail.com \\ ${ }^{3}$ Embrapa Semiárido. Petrolina, PE. E-mail: magna.moura@embrapa.br; ghermangarcia@hotmail.com
}

\section{Key words:}

mulching

intercropping

irrigated forage cactus

capacitive probe

\begin{abstract}
A B S T R A C T
The present study evaluated soil moisture $(\theta)$ in forage cactus plantations under resilience practices such as irrigation, mulching and intercropping with sorghum. The experiment was arranged in a randomized block design with five water availability conditions $(0,8.75$, $17.5,26.25$ and $35 \%$ of the reference evapotranspiration), and three planting systems: forage cactus exclusive system (PE), forage cactus with mulch (PC) and intercropping between forage cactus and sorghum (PS). Water content was measured until a depth of $0.60 \mathrm{~m}$. Meteorological data were recorded between June 2012 and June 2013. Water content was not affected by different resilience practices and the variation coefficient was low to medium (4.0 to $22.1 \%$ ). The temporal variation of soil moisture was more affected by the changes in rainfall, while the physical properties (soil density, porosity and grain size) were decisive in the vertical variation. It was concluded that periods with rainfall events favor the alternation of practices to improve forage cactus resilience (irrigation, mulch and intercropping).
\end{abstract}

Palavras-chave:

cobertura morta consórcio palma irrigada sonda capacitiva

\section{Umidade do solo em lavouras de palma forrageira com práticas de melhoria da sua resiliência}

\section{R E S U M O}

No presente estudo a umidade do solo $(\theta)$ foi avaliada em lavouras de palma forrageira sob práticas resilientes, tais como irrigação, cobertura morta e consórcio com a cultura do sorgo. O experimento foi disposto em blocos ao acaso com parcelas de cinco condições de disponibilidade hídrica $(0,8,75,17,5,26,25$ e $35 \%$ da evapotranspiração de referência) e subparcelas de três sistemas de cultivo: palma exclusiva (PE), palma com cobertura morta (PC) e consórcio palma-sorgo (PS). O monitoramento da umidade do solo foi feito até a profundidade de 0,60 m. Dados meteorológicos foram registrados entre junho de $2012 \mathrm{e}$ junho de 2013. A umidade do solo não foi afetada pelas diferentes práticas para melhoria da resiliência e o coeficiente de variação foi de baixo a médio (4,0 a 22,1\%). O aumento das lâminas de água, cobertura morta e as camadas mais profundas do solo promoveram menores variabilidades da $\theta$. A variação temporal da umidade foi mais afetada pelas alterações da precipitação enquanto as propriedades físicas (densidade do solo, porosidade e frações granulométricas) foram decisivas na variação vertical. Conclui-se que períodos com ocorrência de eventos de chuva favorecem a alternância de práticas de melhoria da resiliência da palma forrageira (irrigação, cobertura morta e consórcio). 


\section{INTRODUCTION}

Soil moisture $(\theta)$ is an essential factor for the biophysical and hydrological processes that sustain the functions of the ecosystems, especially in arid and semi-arid regions, and there is strong correlation between yield and water availability (Yang et al., 2014).

Water content is a variable that has large spatial-temporal variability (Silva et al., 2015b) because, besides depending on meteorological elements, it is related to factors of vegetation, topography, soil texture and depth, and type of cover (Lei et al., 2011). The different management practices can also modify the water dynamics in the soil (Jost et al., 2012; Yang et al., 2014).

In the Brazilian semi-arid region, the high spatial-temporal variability of the water regime and, consequently, of water content, limits the large-scale agricultural production. Thus, the installation of forage cactus plantations is strategic for animal diet supplementation in the most critical period of the year (Silva et al., 2015a).

Although forage cactus is adapted to environments with high water restriction, the use of resilience improvement practices can maximize its yield. The use of irrigation in plantations of this species has been recorded in the last two decades (Queiroz et al., 2015). On the other hand, the adoption of mulching, despite being important in the production systems of various agricultural crops (Kumar \& Dey, 2011), has not yet been reported for this plant. Intercropping of forage cactus with other crops is more common, but under rainfed conditions (Silva et al., 2013).

The knowledge on water content variability allows to improve the conduction of the agricultural crops and use of water resources (Silva et al., 2015a). Therefore, this study aimed to evaluate water content variation in forage cactus plantations under resilience practices in the Brazilian semi-arid region.

\section{Material AND Methods}

The experiment was carried out at the Experimental Station of the Agronomic Institute of Pernambuco (7o 56' 20" S; $38^{\circ}$ 17' 31" W; $498 \mathrm{~m}$ ), in Serra Talhada-PE, Brazil. The climate is semi-arid, with mean annual rainfall of $657 \mathrm{~mm}$ and mean reference evapotranspiration of $2232 \mathrm{~mm}$ year-1 ${ }^{-1}$ according to a provisional series of 16 years (2000-2015) of the Pernambuco Agency for Water and Climate (www.apac.pe.gov.br).

The soil in the studied area is Red Yellow Argisol (EMBRAPA, 2013), with the following mean physical characteristics, obtained for every $0.10 \mathrm{~m}$ until the depth of $0.60 \mathrm{~m}$ according to the methodology of EMBRAPA (1997): $1.5 \mathrm{~kg} \mathrm{dm}^{-3}$ (soil density), $2.6 \mathrm{~kg} \mathrm{dm}^{-3}$ (particle density), $40.8 \%$ (total porosity), $662.8 \mathrm{~g} \mathrm{~kg}^{-1}$ (total sand), $273.4 \mathrm{~g} \mathrm{~kg}^{-1}$ (silt) and $63.8 \mathrm{~g} \mathrm{~kg}^{-1}$ (clay).

The forage cactus 'Orelha de Elefante Mexicana' (Opuntia stricta (haw.) Haw.) was planted in March 2011 at spacing of $1.6 \times 0.4 \mathrm{~m}$, grown in an exclusive cultivation system under rainfed conditions until May 2012, when the standardizing cut was performed, maintaining only the basal cladodes. The second production cycle started in June 2012 and ended in June 2013 (380 days), of the present study.
In this last cycle, the practices of irrigation, mulching and intercropping were adopted, arranged in randomized blocks, $5 \times 3$ factorial scheme and split plots, with four replicates, in which the plots consisted of five water availability conditions $(0 ; 8.75 ; 17.5 ; 26.25$ and $35 \%$ of reference evapotranspiration ETo), and the subplots consisted of three cultivation conditions: forage cactus in exclusive system (PE); forage cactus in exclusive system with mulch (PC); and intercropping between forage cactus and sorghum (PS).

The five water availability levels based on the ETo fractions were established using the data of crop coefficient found by Consoli et al. (2013) for the forage cactus Opuntia ficus-indica L. (Mill.), 10 years old, in Sicily, Italy.

Mulching was implemented at the end of August 2012, when the subplots received the equivalent to $8.2 \mathrm{t} \mathrm{ha}^{-1}$ of residues from weeds existing in the surroundings of the experimental area, where narrow-leaf plants prevailed. There was no replacement of the mulch over time.

The system intercropped with sorghum (cv. 'IPA 2501') started at the beginning of November 2012, and the crop was sown in single row at depth of $0.05 \mathrm{~m}, 0.25 \mathrm{~m}$ away from the forage cactus, using fifteen seeds per linear meter, which resulted in a planting density of 170,000 plants ha-1. Sorghum was conducted for two production cycles (plant and regrowth), the first one harvested in February 2013 and the second one in June 2013, totaling 246 days, within the 380 days of the forage cactus cycle.

A drip irrigation system was used, with drippers spaced at $0.40 \mathrm{~m}$, flow rate of $1.35 \mathrm{~L} \mathrm{~h}^{-1}$ at pressure of $100 \mathrm{kPa}$ and mean coefficient of distribution of $93 \%$. In the intercropping, the drip tape was placed between the rows of forage cactus and sorghum.

The irrigation depths were identical in the three cultivation systems (PE, PC and PS) until the end of November 2012 $(583 \mathrm{~mm})$ (Table 1), to guarantee the establishment of the crop. From December 5, 2012 on, different irrigation depths started to be applied $(0 ; 8.75 ; 17.5 ; 26.25$ and 35\% ETo), until June 19, 2013. The applied irrigation depths were: $(583+0$ $+393)=976 ;(583+72+393)=1048 ;(583+120+393)=$ $1096,(583+176+393)=1152$ and $(583+226+393)=1202$ $\mathrm{mm}$, in which $0,72,120,176$ and $226 \mathrm{~mm}$ refer to the different irrigation depths and $393 \mathrm{~mm}$ the rainfall, out of which 371 mm occurred between December 5, 2012 and June 19, 2013.

The meteorological variables (global solar radiation, $\mathrm{MJ} \mathrm{m} \mathrm{m}^{-2} \mathrm{~d}^{-1}$; air temperature, ${ }^{\circ} \mathrm{C}$; relative air humidity, \%; atmospheric pressure, $\mathrm{hPa}$; and wind speed at height of 10 meters, $\mathrm{m} \mathrm{s}^{-1}$ ) were obtained from an automatic station of the National Institute of Meteorology (www.inmet.gov.br) for the calculation of the reference evapotranspiration (Allen et al., 1998). Pluviometric precipitation (mm), in turn, was obtained from a pluviometric station of the Pernambuco Agency for Water and Climate (www.apac.pe.gov.br).

Soil moisture $(\theta)$ was monitored using access tubes and a capacitive probe (model Diviner@2000 Sentek Pty Ltda., Australia) locally calibrated, as described by Araújo Primo et al. (2015). One access tube was installed in each subplot. The readings were taken at intervals of two days from June 6, 2012 to June 19,2013 , with measurement of the relative frequency 
Table 1. Meteorological variables and irrigation depths between Jun-2012 and Jun-2013, in forage cactus plantations under resilience practices in Serra Talhada-PE

\begin{tabular}{|c|c|c|c|c|c|c|c|c|c|c|c|c|c|c|}
\hline \multirow{2}{*}{ Month/Year } & $\mathrm{tm}$ & $\mathrm{tx}$ & tn & $\mathrm{RHm}$ & RHx & RHn & \multirow{2}{*}{$\begin{array}{c}\mathrm{u} 10 \\
\left(\mathrm{~m} \mathrm{~s}^{-1}\right)\end{array}$} & \multirow{2}{*}{$\begin{array}{c}\mathrm{Rg} \\
\left(\mathrm{MJ} \mathrm{m}^{-2} \mathrm{~d}^{-1}\right)\end{array}$} & Prec. & LO\% & L8.75\% & L17.5\% & L26.25\% & L35\% \\
\hline & & $\left({ }^{\circ} \mathrm{C}\right)$ & & & $(\%)$ & & & & \multicolumn{6}{|c|}{$(\mathrm{mm})$} \\
\hline Jun-2012 & 25.2 & 31.2 & 20.1 & 55.6 & 81.2 & 30.5 & 2.7 & 18.1 & 2 & 24 & 24 & 24 & 24 & 24 \\
\hline Jul-2012 & 23.8 & 30.0 & 19.0 & 59.4 & 83.0 & 32.5 & 3.3 & 18.2 & 12 & 90 & 90 & 90 & 90 & 90 \\
\hline Aug-2012 & 23.7 & 30.4 & 18.5 & 56.0 & 82.3 & 27.7 & 3.7 & 20.3 & 5 & 120 & 120 & 120 & 120 & 120 \\
\hline Sep-2012 & 25.7 & 32.7 & 19.3 & 46.8 & 75.0 & 22.6 & 3.3 & 23.8 & 1 & 92 & 92 & 92 & 92 & 92 \\
\hline Oct-2012 & 26.9 & 34.0 & 20.7 & 46.0 & 71.9 & 22.1 & 3.2 & 24.4 & 0 & 110 & 110 & 110 & 110 & 110 \\
\hline Nov-2012 & 28.9 & 35.7 & 22.5 & 40.7 & 68.7 & 17.4 & 2.9 & 24.7 & 2 & 147 & 147 & 147 & 147 & 147 \\
\hline Dec-2012 & 28.7 & 35.2 & 23.0 & 43.3 & 68.8 & 8.6 & 2.5 & 24.3 & 7 & 0 & 23 & 31 & 43 & 52 \\
\hline Jan-2013 & 27.7 & 33.9 & 22.6 & 51.0 & 77.5 & 26.0 & 2.3 & 21.8 & 110 & 0 & 17 & 23 & 31 & 38 \\
\hline Feb-2013 & 28.5 & 34.9 & 22.8 & 45.1 & 71.4 & 21.5 & 2.7 & 24.6 & 20 & 0 & 10 & 20 & 31 & 41 \\
\hline Mar-2013 & 28.3 & 34.6 & 23.1 & 50.5 & 75.0 & 26.0 & 2.3 & 24.6 & 69 & 0 & 9 & 18 & 28 & 38 \\
\hline Apr-2013 & 26.5 & 32.6 & 22.2 & 60.4 & 83.4 & 32.5 & 2.4 & 22.3 & 113 & 0 & 5 & 11 & 17 & 22 \\
\hline May-2013 & 25.3 & 31.0 & 20.7 & 63.5 & 85.4 & 36.9 & 2.2 & 21.4 & 48 & 0 & 5 & 10 & 15 & 21 \\
\hline Jun-2013* & 24.9 & 30.8 & 20.3 & 59.6 & 83.4 & 33.4 & 2.4 & 16.4 & 5 & 0 & 3 & 7 & 11 & 14 \\
\hline Means/Sum & 26.5 & 32.9 & 21.2 & 52.1 & 77.5 & 26.0 & 2.7 & 21.9 & 393 & 583 & 655 & 703 & 759 & 809 \\
\hline
\end{tabular}

$\mathrm{tm}$ - Mean air temperature; tx - Maximum air temperature; tn - Minimum air temperature; RHm - Mean relative air humidity; RHx - Maximum relative air humidity; RHn - Minimum relative air humidity; $u 10$ - Wind speed at height of $10 \mathrm{~m}$; Rg - Global solar radiation; Prec. - Pluviometric precipitation; L - Irrigation depths based on the reference evapotranspiration fractions (8.75; $17.5 ; 26.25$ and $35 \%$ ETo). *Refer to first 19 days

and conversion to $\theta$ at every $0.10 \mathrm{~m}$ until the depth of $0.60 \mathrm{~m}$ (mean depths: $0.05 ; 0.15 ; 0.25 ; 0.35 ; 0.45$ and $0.55 \mathrm{~m}$ ).

Means of $\theta$ data every 14 days were established, resulting in 14 periods between December 5, 2012 and June 19, 2013 (interval with the application of all treatments), for the analysis of the seasonal variation of $\theta$ and its association with the other factors in action (irrigation depth, cultivation system, depth).

Mean, standard deviation and coefficient of variation relative to the soil moisture data were calculated for the different irrigation depths, cultivation systems, depths and periods. The variability of $\theta$ was evaluated by the coefficient of variation (CV) with the limits defined by Warrick \& Nielsen (1980): low (CV $<12 \%)$; intermediate $(12 \%<\mathrm{CV}<60 \%)$ and high $(\mathrm{CV}>60 \%)$.

The Lilliefors normality test was used and, subsequently, analysis of variance was performed ( $F$ test, $\alpha=0.05$ ) to evaluate the effects of the factors irrigation, cultivation system, depths and periods, and their respective double, triple or quadruple interactions on soil moisture. When the factor period was incorporated in the analysis, the ANOVA was applied, with measurement repeated over time. Fisher's LSD (least significant difference) test of means was used when necessary ( $\alpha=0.05)$.

Regressions were established between the mean $\theta$ data and soil physical properties per depth. Pearson's linear correlation matrix was adopted between $\theta$ data and the mean or cumulative values of the meteorological variables and of the irrigation depths between the $\theta$ reading intervals.

\section{Results AND Discussion}

During the period of simultaneous application of the three resilience practices (Dec 05, 2012 to Jun 19, 2013), the irrigation depths did not affect the magnitude of $\theta$ ( $p>$ 0.05 ), although the increase in water availability reduced its variability (Table 2 ).

Likewise, the adoption of mulching or intercropping with sorghum did not affect $\theta$, in relation to the conventional system of exclusive cultivation of forage cactus, showing intermediate CV (Table 2). However, the mulch decreased the variability of soil moisture (15.7\%) and the forage cactus-sorghum intercropping resulted in higher CV (22.1\%).
Mulching decreased the evaporation rate and, consequently, the variation of soil moisture (Kumar \& Dey, 2011). About low variability of $\theta$, Fu et al. (2012) cite that the production stability of agricultural crops can be favored.

On the other hand, the higher variability in the forage cactus-sorghum intercropping can be justified by the water dynamics promoted by the presence of the root systems of two crops in the superficial soil layers, which intensified the water transfer to the atmosphere, especially when water is replaced more frequently.

Because of that, the most superficial layers of the soil showed the highest values of CV for $\theta$, gradually decreasing as depth increased (Table 2). However, this result depends on the adopted resilience practice and on soil physical characteristics.

There was only effect of the factor period and its interactions with irrigation depth, cultivation system and depth on $\theta$ ( $\mathrm{p}>$ 0.05 ) (Table 2), due to the seasonality of water entry in the forage cactus cultivation areas (Table 1).

The period 4 showed the highest $\theta$ and low CV (Table 2), due to the rainfall events occurred in January 2013 (Table 1). In the periods 1 and 11 , soil moisture also was high, but with $\mathrm{CV}$ ranging from low to intermediate; the first one occurred after December 2012, when the irrigation depths were applied, and the second one in April 2013, when the pluviometric levels were also higher.

The CV for the different factors evaluated (irrigation depth, cultivation system, depth and period), in general, was characterized as low to intermediate, indicating that in the period of highest occurrence of rainfall the alternation of resilience practices in forage cactus plantations does not modify soil moisture dynamics.

Despite the lack of difference of $\theta$ between the depths in the period of simultaneous occurrence of the resilience practices, there were peculiarities in the magnitude and in the CV over time, depending on soil depth (Figure 1A).

In the first days after the beginning of the cycle, when the water entry was still reduced, $\theta$ was low $\left(<0.10 \mathrm{~m}^{3} \mathrm{~m}^{-3}\right)$. Thus, with the application of a higher irrigation depth $(66 \mathrm{~mm})$ and 
Table 2. Mean soil moisture and significance levels per factor (irrigation depth, cultivation system, depth and period of the cycle) and their interactions in forage cactus plantations under resilience improvement practices, in Serra Talhada-PE

\begin{tabular}{|c|c|c|c|c|c|}
\hline & $\begin{array}{l}\text { Levels } \\
\text { of factors }\end{array}$ & $\begin{array}{c}\boldsymbol{\mu} \\
\left(\mathbf{m}^{3} \mathbf{m}^{-3}\right)\end{array}$ & $\begin{array}{c}\text { SD } \\
\left(\mathrm{m}^{3} \mathrm{~m}^{-3}\right)\end{array}$ & $\begin{array}{l}\text { CV } \\
(\%)\end{array}$ & $\mathbf{n}$ \\
\hline \multirow{5}{*}{$\begin{array}{l}\text { Irrigation depth } \\
\qquad(\mathrm{mm})\end{array}$} & 0\% ETo & 0.176 & 0.037 & 21.4 & 6120 \\
\hline & $8.75 \%$ ETo & 0.179 & 0.038 & 21.9 & 6120 \\
\hline & $17.5 \%$ ETo & 0.183 & 0.031 & 17.7 & 6120 \\
\hline & $26.25 \%$ ETo & 0.190 & 0.031 & 16.6 & 6120 \\
\hline & $35 \%$ ETo & 0.191 & 0.025 & 13.0 & 6120 \\
\hline \multirow{3}{*}{ System } & PE & 0.189 & 0.031 & 16.6 & 10200 \\
\hline & PC & 0.181 & 0.028 & 15.7 & 10200 \\
\hline & PS & 0.181 & 0.039 & 22.1 & 10200 \\
\hline \multirow{6}{*}{$\begin{array}{l}\text { Depth } \\
\text { (m) }\end{array}$} & 0.05 & 0.187 & 0.037 & 20.4 & 5100 \\
\hline & 0.15 & 0.175 & 0.031 & 18.3 & 5100 \\
\hline & 0.25 & 0.176 & 0.031 & 17.7 & 5100 \\
\hline & 0.35 & 0.182 & 0.032 & 17.5 & 5100 \\
\hline & 0.45 & 0.189 & 0.032 & 17.4 & 5100 \\
\hline & 0.55 & 0.193 & 0.033 & 17.3 & 5100 \\
\hline \multirow{14}{*}{ Period* } & 1 (Dec-05-2012 to Dec-19-2012) & 0.202 b & 0.008 & 4.1 & 2520 \\
\hline & 2 (Dec-20-2012 to Jan-02-2013) & $0.191 \mathrm{bcd}$ & 0.009 & 4.9 & 2160 \\
\hline & 3 (Jan-03-2013 to Jan-16-2013) & 0.184 cde & 0.007 & 4.0 & 2160 \\
\hline & 4 (Jan-17-2013 to Jan-30-2013) & $0.223 \mathrm{a}$ & 0.021 & 9.4 & 2160 \\
\hline & 5 (Jan-31-2013 to Feb-13-2013) & $0.191 \mathrm{bcd}$ & 0.015 & 8.3 & 2160 \\
\hline & 6 (Feb-14-2013 to Feb-27-2013) & $0.173 \mathrm{fg}$ & 0.012 & 7.0 & 2160 \\
\hline & 7 (Feb-28-2013 to Mar-13-2013) & $0.162 \mathrm{gh}$ & 0.008 & 5.1 & 2160 \\
\hline & 8 (Mar-14-2013 to Mar-27-2013) & $0.163 \mathrm{gh}$ & 0.008 & 4.9 & 2160 \\
\hline & 9 (Mar-28-2013 to Apr-10-2013) & $0.173 \mathrm{fg}$ & 0.019 & 11.1 & 2160 \\
\hline & 10 (Apr-11-2013 to Apr-24-2013) & 0.177 def & 0.010 & 5.8 & 2160 \\
\hline & 11 (Apr-25-2013 to May-08-2013) & $0.200 \mathrm{~b}$ & 0.032 & 16.5 & 2160 \\
\hline & 12 (May-09-2013 to May-22-2013) & $0.193 \mathrm{bc}$ & 0.016 & 9.2 & 2160 \\
\hline & 13 (May-23-2013 to Jun-05-2013) & $0.168 \mathrm{gh}$ & 0.012 & 7.4 & 2160 \\
\hline & 14 (Jun-06-2013 to Jun-19-2013) & $0.155 \mathrm{~h}$ & 0.009 & 5.6 & 2160 \\
\hline \multirow{14}{*}{$\begin{array}{l}\text { Significance } \\
\text { level** }^{\star *}\end{array}$} & Irrigation depth & $(\mathrm{L})$ & & & 0.691 \\
\hline & System & (S) & & & 0.660 \\
\hline & Depth & (D) & & & 0.296 \\
\hline & Period & (P) & & & $<0.0001$ \\
\hline & $L \times S$ & & & & 0.249 \\
\hline & $L \times D$ & & & & 0.302 \\
\hline & $L x P$ & & & & $<0.0001$ \\
\hline & $S \times D$ & & & & 0.540 \\
\hline & $S \times P$ & & & & $<0.0001$ \\
\hline & $D \times P$ & & & & $<0.0001$ \\
\hline & $L \times S \times D$ & & & & 0.026 \\
\hline & $L \times S \times P$ & & & & $<0.0001$ \\
\hline & SxD $\times P$ & & & & $<0.0001$ \\
\hline & LxS XDXP & & & & $<0.0001$ \\
\hline
\end{tabular}

Irrigation depths $(0,8.75,17.5,26.25$ and 35\% ETo); Cultivation systems (PE - Exclusive system; PC - With mulching: PS - Forage cactus-sorghum intercropping); $\mu$ - Mean, SD - Standard deviation; CV - Coefficient of variation; $n$ - Number of observations; *Separation of the means by the Fisher's LSD (least significant difference) test $(\alpha=0.05)$; **Significance level by the F test $(\alpha=0.05)$

the persistence of various events over time, the $\theta$ increased at all depths, remaining between 0.15 to $0.25 \mathrm{~m}^{3} \mathrm{~m}^{-3}$ until the moment of the differentiation of the irrigation depths (December 5, 2012).

From this date on and although the different irrigation regimes were conducted, the number of events was reduced because of the occurrence of various rainy days. Consequently, $\theta$ was more conditioned by the rainfall. The highest $\theta$ values occurred immediately after the most intense events of irrigation or precipitation, or during the days with successive rainfall events. At the end of the cycle, with the reduction in precipitation and suspension of irrigation, $\theta$ decreased until the harvest of the forage cactus (June 19, 2013).

According to Figure $1 \mathrm{~B}$, it is noticed that, in the period without differentiation of irrigation depths but with highest occurrence of irrigation events, immediately after the application of the first most intense event $(66 \mathrm{~mm})$, the $\mathrm{CV}$ of the first layer increased rapidly. From this moment on, the CV was lower in the more superficial layers and tended to increase with depth, reaching values above $20 \%$.

With the use of mulch, there was a reduction of $\mathrm{CV}$ at all depths until the beginning of the differentiation of the irrigation depths. However, in the first days after this last moment, when the rainfall events were still only a few, the $\mathrm{CV}$ increased in the first layer. This repeated at the end of the cycle with the suspension of irrigation and occurrence of few rainfall events (Figure 1B). Between these two moments, when the days with rainfalls were more common, the CV was lower in the first layers and higher in the deeper layers, but its magnitudes were more similar compared with the other periods of the cycle.

The significant correlation between the $\theta$ values of the soil profile under the different resilience practices (irrigation depths, mulch and intercropping) (Table 3) indicates high 
A. Period WITHOUT differentiation Period WITH differentiation of irrigation depths of irrigation depths

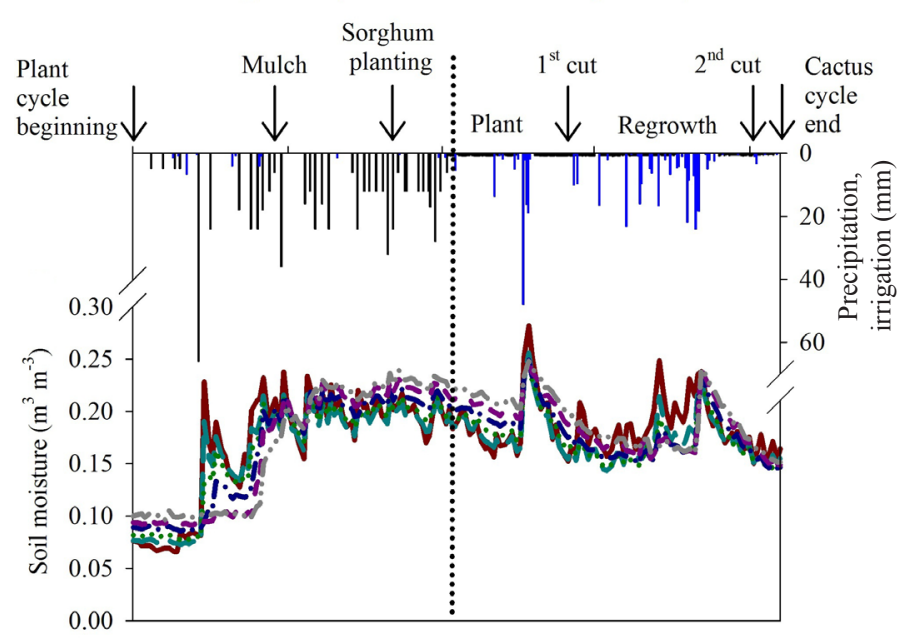

B. Period WITHOUT differentiation Period WITH differentiation of irrigation depths of irrigation depths

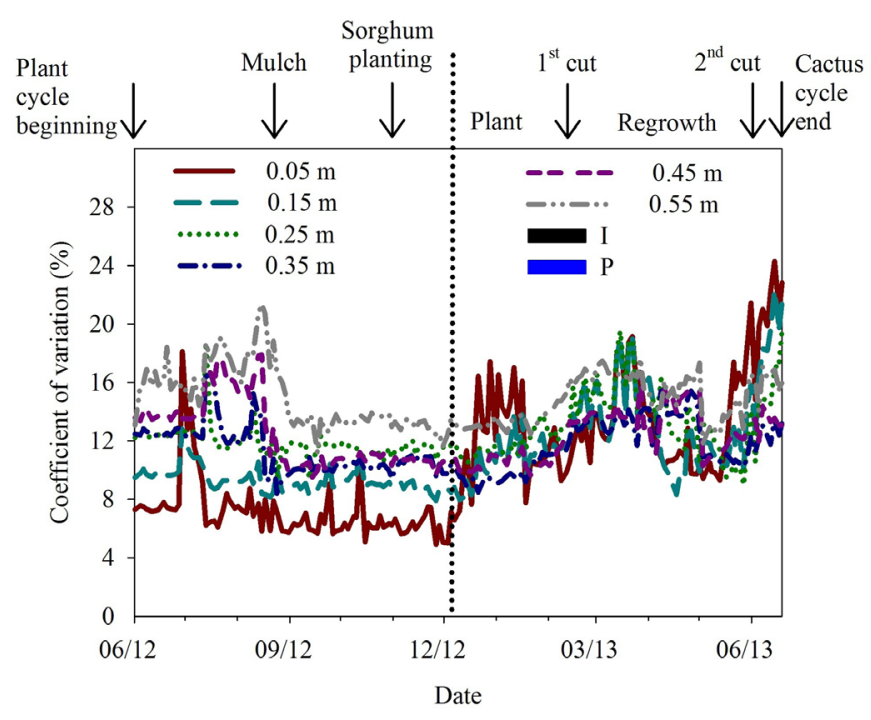

I and $\mathrm{P}$ - Indicate irrigation and pluviometric precipitation, respectively

Figure 1. Temporal variation of mean soil moisture (A) and coefficient of variation (B) in forage cactus plantations under resilience practices, in Serra Talhada-PE

Table 3. Pearson's correlation coefficient between meteorological variables, irrigation depths and moisture data $(\theta)$ of the soil cultivated with forage cactus under resilience practices, in Serra Talhada-PE, between December 5, 2012 and June 19, 2013

\begin{tabular}{|c|c|c|c|c|c|c|c|c|}
\hline Variables & $\theta(0 \%-P E)$ & $\theta(8.75 \%-\mathrm{PE})$ & $\theta(17.5 \%-P E)$ & $\theta(26.25 \%-P E)$ & $\theta(35 \%-P E)$ & $\theta(0 \%-P C)$ & $\theta(8.75 \%-P C)$ & $\theta(17.5 \%-P C)$ \\
\hline$\theta(8.75 \%-P E)$ & 0.960 & - & - & - & - & - & - & - \\
\hline$\theta(17.5 \%-\mathrm{PE})$ & 0.950 & 0.960 & - & - & - & - & - & - \\
\hline$\theta$ (26.25\%-PE) & 0.900 & 0.900 & 0.960 & - & - & - & - & - \\
\hline$\theta(35 \%-P E)$ & 0.820 & 0.820 & 0.890 & 0.890 & - & - & - & - \\
\hline$\theta(976-P C)$ & 0.970 & 0.980 & 0.950 & 0.890 & 0.860 & - & - & - \\
\hline$\theta(8.75 \%-P C)$ & 0.920 & 0.900 & 0.930 & 0.890 & 0.890 & 0.920 & - & - \\
\hline$\theta(17.5 \%-P C)$ & 0.920 & 0.900 & 0.920 & 0.820 & 0.830 & 0.950 & 0.900 & - \\
\hline$\theta(26.25 \%-P C)$ & 0.860 & 0.880 & 0.910 & 0.870 & 0.820 & 0.860 & 0.850 & 0.830 \\
\hline$\theta(35 \%-P C)$ & 0.640 & 0.620 & 0.760 & 0.660 & 0.810 & 0.700 & 0.750 & 0.780 \\
\hline$\theta(0 \%-P S)$ & 0.980 & 0.970 & 0.950 & 0.900 & 0.840 & 0.960 & 0.950 & 0.890 \\
\hline$\theta(8.75 \%-P S)$ & 0.910 & 0.910 & 0.940 & 0.850 & 0.890 & 0.920 & 0.900 & 0.950 \\
\hline$\theta(17.5 \%-P S)$ & 0.960 & 0.950 & 0.930 & 0.840 & 0.800 & 0.970 & 0.920 & 0.930 \\
\hline$\theta(26.25 \%-P S)$ & 0.840 & 0.840 & 0.870 & 0.750 & 0.760 & 0.870 & 0.880 & 0.890 \\
\hline$\theta(35 \%-P S)$ & 0.900 & 0.930 & 0.900 & 0.790 & 0.780 & 0.920 & 0.900 & 0.870 \\
\hline $\mathrm{RHm}$ & 0.550 & $0.500 \mathrm{~ns}$ & 0.610 & 0.640 & 0.600 & $0.520 \mathrm{~ns}$ & 0.610 & $0.460 \mathrm{~ns}$ \\
\hline U & $-0.450 \mathrm{~ns}$ & $-0.470 \mathrm{~ns}$ & -0.610 & -0.600 & -0.600 & $-0.480 \mathrm{~ns}$ & -0.560 & -0.570 \\
\hline Prec & 0.640 & 0.730 & 0.810 & 0.700 & 0.710 & 0.690 & 0.700 & 0.710 \\
\hline Prec. + I (8.75\%) & 0.640 & 0.730 & 0.810 & 0.700 & 0.710 & 0.690 & 0.690 & 0.710 \\
\hline Prec. + I (17.5\%) & 0.640 & 0.730 & 0.810 & 0.700 & 0.700 & 0.680 & 0.690 & 0.710 \\
\hline Prec. + I (26.25\%) & 0.630 & 0.720 & 0.810 & 0.700 & 0.700 & 0.680 & 0.680 & 0.710 \\
\hline Prec. + I $(35 \%)$ & 0.620 & 0.710 & 0.810 & 0.690 & 0.690 & 0.670 & 0.670 & 0.710 \\
\hline Variables & $\theta(26.25 \%-P C)$ & $\theta(35 \%-P C)$ & $\theta$ (0\%-PS) & $\theta(8.75 \%-P S)$ & $\theta$ (17.5\%-PS) & $\theta(26.25 \%-P S)$ & $\theta$ (35\%-PS) & - \\
\hline$\theta(35 \%-P C)$ & 0.780 & - & - & - & - & - & - & - \\
\hline$\theta(0 \%-P S)$ & 0.880 & 0.640 & - & - & - & - & - & - \\
\hline$\theta(8.75 \%-P S)$ & 0.900 & 0.780 & 0.910 & - & - & - & - & - \\
\hline$\theta(17.5 \%-P S)$ & 0.900 & 0.720 & 0.960 & 0.910 & - & - & - & - \\
\hline$\theta(26.25 \%-P S)$ & 0.880 & 0.880 & 0.840 & 0.860 & 0.920 & - & - & - \\
\hline$\theta(35 \%-P S)$ & 0.910 & 0.740 & 0.930 & 0.900 & 0.970 & 0.940 & - & - \\
\hline $\mathrm{RHm}$ & 0.690 & 0.680 & 0.600 & $0.510 \mathrm{~ns}$ & 0.580 & 0.630 & 0.590 & - \\
\hline U & -0.650 & -0.730 & $-0.440 \mathrm{~ns}$ & -0.660 & $-0.440 \mathrm{~ns}$ & -0.630 & $-0.510 \mathrm{~ns}$ & - \\
\hline Prec & 0.840 & 0.820 & 0.680 & 0.810 & 0.730 & 0.830 & 0.810 & - \\
\hline Prec. + I (8.75\%) & 0.830 & 0.820 & 0.680 & 0.800 & 0.720 & 0.830 & 0.800 & - \\
\hline Prec. + I (17.5\%) & 0.830 & 0.820 & 0.670 & 0.800 & 0.720 & 0.830 & 0.790 & - \\
\hline Prec. + I (26.25\%) & 0.820 & 0.820 & 0.660 & 0.800 & 0.710 & 0.820 & 0.780 & - \\
\hline Prec. + I $(35 \%)$ & 0.810 & 0.820 & 0.650 & 0.790 & 0.700 & 0.820 & 0.780 & - \\
\hline
\end{tabular}

Irrigation depths (0, 8.75, 17.5, 26.25 and 35\% ETo); Cultivation systems (PE - Forage cactus exclusive system; PC - Forage cactus with mulch; PS - Forage cactus-sorghum intercropping) Prec. + I - Pluviometric precipitation plus irrigation; ns - Values were not significant $(p>0.05)$ 
uniformity of the spatial distribution of $\theta$ in the period from December 5, 2012 to June 19, 2013, regardless of the different irrigation depths.

This fact can be explained by the reduced number of irrigation events in this period, when rainy days prevailed. Thus, the correlation coefficients between $\theta$ and pluviometric precipitation, and between $\theta$ and pluviometric precipitation plus irrigation were very similar, showing the small effect of irrigation with the intensification of the rainfalls.

The contribution of the other meteorological variables to the temporal variation of $\theta$ was evidenced only by the relative air humidity and wind speed, which condition the water vapor pressure deficit in the atmosphere (VPD). However, although significant, the magnitude was moderate (Table 3). Since forage cactus is a cactaceous species, its transpiration occurs more at night, when the VPD is lower. In other types of vegetation, of non-cactaceous plants, the air temperature and global solar radiation gain more importance, because they affect the actual evapotranspiration and, consequently, the $\theta$ (Wang et al., 2015).

The spatial-temporal variation of $\theta$ was associated with the physical properties along the soil profile. In this analysis, the

A. Total porosity (Ptotal, \%)

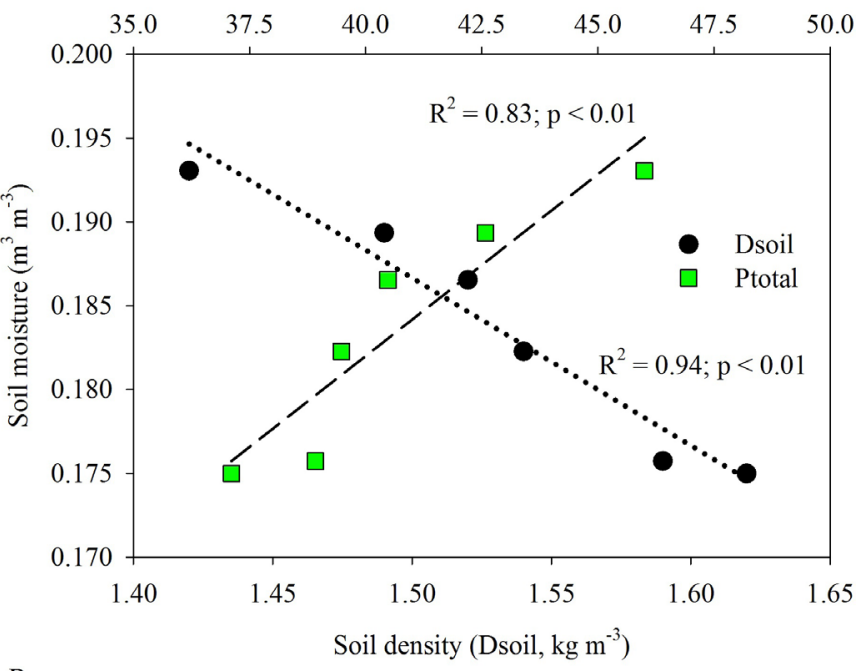

B.

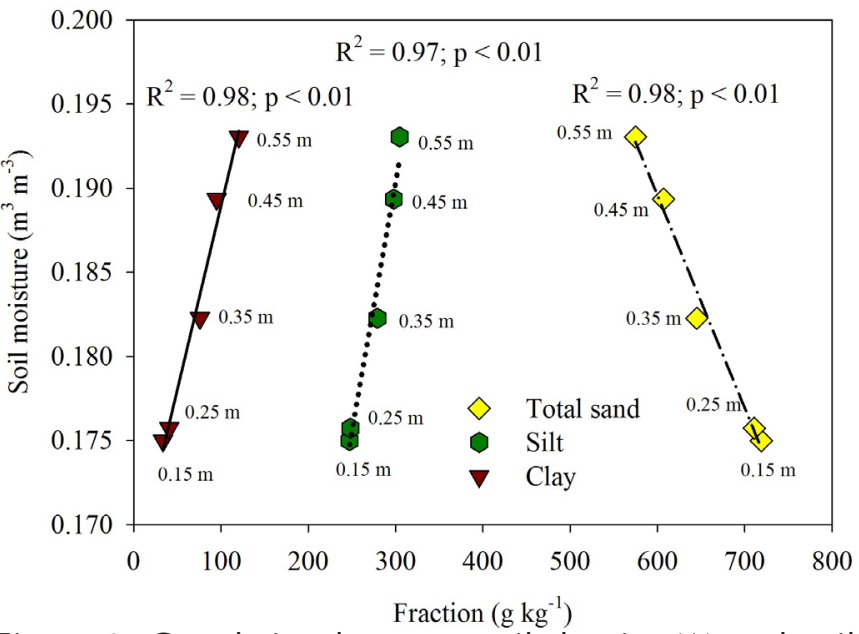

Figure 2. Correlation between soil density (A) and soil moisture with the granulometric fractions (B) of a Red Yellow Argisol cultivated with forage cactus under different resilience practices, in Serra Talhada-PE highest $\theta$ occurred in the layers with lower soil density, but with higher total porosity (Figure 2A).

Ramos et al. (2013) explain that, despite the low density of a soil, the higher total porosity indicates the presence of macropores that favor water retention when the tension is low. Under this condition, water distribution along the profile is more uniform, as observed in the present study.

The granulometric characteristic of the soil also influenced $\theta$ distribution along the profile, except for the first layer, which responds more rapidly to the irrigation events and to the variability of meteorological conditions (Figure 2B).

\section{Conclusions}

1. The adoption of different irrigation depths, mulching or intercropping with sorghum did not affect the magnitude of soil moisture under forage cactus cultivation.

2. The lowest variabilities of soil moisture occurred under the conditions of higher water availability, use of mulch and in the deepest layers.

3. The temporal variation of soil moisture was more affected by the alterations of rainfall, while the physical properties were decisive in the vertical variation.

4. Periods with occurrence of rainfall events favor the alternation of resilience improvement practices of forage cactus (irrigation, mulching and intercropping).

\section{ACKNOWLeDgments}

To the National Council for Scientific and Technological Development (CNPq), for the financial support (475279/20107) and to the Coordination for the Improvement of Higher Education Personnel (CAPES), for granting the scholarship.

\section{Literature Cited}

Allen, R. G.; Pereira, L. S.; Raes, D.; Smith, M. Crop evapotranspiration: Guidelines for computing crop water requirements. 1.ed. Rome: FAO, 1998. 297p.

Araújo Primo, J. T. de; Silva, T. G. F. da; Silva, S. M. S. e; Moura, M. S. B. de; Souza, L. S. B. de. Calibração de sondas capacitivas, funções físico-hídricas e variação do armazenamento de água em um argissolo cultivado com palma forrageira. Revista Ceres, v.62, p.20-29, 2015. https://doi.org/10.1590/0034-737X201562010003

Consoli, S.; Inglese, G.; Inglese, P. Determination of evapotranspiration and annual biomass productivity of a cactus pear (Opuntia ficus indica L. (Mill.) orchard in a semi-arid environment. Journal of Irrigation and Drainage Engineering, v.139, p.680-690, 2013. http://dx.doi.org/10.1061/(ASCE)IR.1943-4774.0000589.

EMBRAPA - Empresa Brasileira de Pesquisa Agropecuária. Manual de métodos de análise de solo. 2.ed. Rio de Janeiro: EMBRAPACNPS, 1997. 212p.

EMBRAPA - Empresa Brasileira de Pesquisa Agropecuária. Sistema brasileiro de classificação de solos. 3.ed. Brasília, 2013. 353p.

Fu, W.; Huang, M.; Gallichand, J.; Shao, M. Optimization of plant coverage in relation to water balance in the Loess Plateau of China. Geoderma, v.173-174, p.134-144, 2012. https://doi.org/10.1016/j. geoderma.2011.12.016 
Jost, G.; Schume, H.; Hager, H.; Markart, G.; Kohl, B. A hillslope scale comparison of tree species influence on soil moisture dynamics and runoff processes during intense rainfall. Journal of Hydrology, v.420-421, p.112-124, 2012. https://doi.org/10.1016/j. jhydrol.2011.11.057

Kumar, S.; Dey, P. Effects of different mulches and irrigation methods on root growth, nutrient uptake, water-use efficiency and yield of strawberry. Scientia Horticulturae, v.127, p.318-324, 2011. https:// doi.org/10.1016/j.scienta.2010.10.023

Lei, Y.; Lubo, G.; Huaxing, B.; Qingke, Z.; Xiaoyan, W. Spatiotemporal dynamics of soil moisture in silvopastoral system in the Loess Plateau of west Shanxi province. Procedia Environmental Sciences, v.8, p.153-160, 2011. https://doi.org/10.1016/j. proenv.2011.10.025

Queiroz, M. G. de; Silva, T. G. F. da; Zolnier, S.; Silva, S. M. S. e; Lima, L. R.; Alves, J. de O. Características morfofisiológicas e produtividade da palma forrageira em diferentes lâminas de irrigação. Revista Brasileira de Engenharia Agrícola e Ambiental, v.19, p.931-938, 2015. https://doi.org/10.1590/1807-1929/ agriambi.v19n10p931-938

Ramos, B. Z.; Pais, P. S. M.; Freitas, W. A.; Dias Júnior, M. de S. Avaliação dos atributos físico-hídricos em um Latossolo Vermelho distroférrico sob diferentes sistemas de manejo Lavras/Minas Gerais/Brasil. Revista de Ciências Agrárias, v.36, p.440-446, 2013.
Silva, G. dos S.; Oliveira, R. A. de; Queiroz, N. L.; Silva, M. N. B. da; Sousa, M. F. de; Silva, S. A. da. Desempenho agronômico de algodão orgânico e oleaginosas consorciados com palma forrageira. Revista Brasileira Engenharia Agrícola Ambiental, v.17, p.975981, 2013. https://doi.org/10.1590/S1415-43662013000900010

Silva, T. G. F. da; Araújo Primo, J. T.; Morais, J. E. F. de; Diniz, W. J. da S.; Souza, C. A. A. de; Silva, M. da C. Crescimento e produtividade de clones de palma forrageira no semiárido e relações com variáveis meteorológicas. Revista Caatinga, v.28, p.10-18, $2015 \mathrm{a}$.

Silva, T. G. F. da; Araújo Primo, J. T.; Moura, M. S. B. de; Silva, S. M. S. e; Morais, J. E. F. de; Pereira, P. de C.; Souza, C. A. A. de. Soil water dynamics and evapotranspiration of forage cactus clones under rainfed conditions. Pesquisa Agropecuária Brasileira, v.50, p.515525, 2015b. https://doi.org/10.1590/S0100-204X2015000700001

Wang, T.; Wedin, D. A.; Franz, T. E.; Hiller, J. Effect of vegetation on the temporal stability of soil moisture in grass-stabilized semi-arid sand dunes. Journal of Hydrology, v.521, p.447-459, 2015. https:// doi.org/10.1016/j.jhydrol.2014.12.037

Warrick, A. W.; Nielsen, D. R. Spatial variability of soil physical properties in the field. In: Hillel, D. Applications of soil physics. 1.ed. New York: Academic, 1980. 319-344p. https://doi. org/10.1016/B978-0-12-348580-9.50018-3

Yang, L.; Wei, W.; Chen, L.; Chen, W.; Wang, J. Response of temporal variation of soil moisture to vegetation restoration in semi-arid Loess Plateau, China. Catena, v.115, p.123-133, 2014. https://doi. $\operatorname{org} / 10.1016 /$ j.catena.2013.12.005 